IJBE: Integrated Journal of Business and Economics

e-ISSN: 2549-3280

\title{
The Prediction of Bankruptcy Using Altman Z-Score Model \\ (Case Study In BRI Bank, BNI Bank, Mandiri Bank, BTN Bank)
}

\author{
Herlin \\ Faculty of Economic, University of Dehasen Bengkulu \\ herlin_olin81@yahoo.com
}

\begin{abstract}
Based on the calculation of the Altman model in predicting bankrupt at PT. Bank Rakyat Indonesia (Persero) Tbk in 2014, 2015, 2016, PT. Bank Mandiri (Persero) Tbk in 2014 and 2015 and is PT.Bank Tabungan Negara (Persero) Tbk in 2014 with a score of Z-score above 2.99 indicates that included in the company healthy or not potential to go bankrupt. Companies included in the category of unhealthy or potential companies to go bankrupt with a Z-score of less than 1.81 ie PT. Bank Tabungan Negara (Persero) Tbk in 2014 with a Z-score of 1.405 (<1.81). Companies included in the Gray Area (unpredictable) are PT. Bank Negara Indonesia (Persero) Tbk 2015 with Z-score of 2, 753 and year 2016 with Z-score 2,858. PT Bank Tabungan Negara in 2015 and 2016 with Z-score of 2,138 and 1,906 and PT. Bank Mandiri (Persero) Tbk in 2016 which shows the value of Z-score of 2,168.
\end{abstract}

Keywords: Altman Model, Financial Distress

\section{Pendahuluan}

Sektor perbankan merupakan sektor keuangan yang mempunyai peranan penting dalam meningkatkan pertumbuhan ekonomi Indonesia. Meningkatnya bisnis dibidang perbankan dari tahun ketahun baik yang bergerak dibidang konvensional atau bank-bank syariah yang semakin menapakan sayapnya di industri perbankan. Untuk itu industri perbankan berlomba-lomba untuk menarik minat masyarakat dalam menggunakan jasa dan produk yang ditawarkan. Salah satu yang menjadi andalan setiap bank adalah dengan meningkatkan kinerja keuangan yang sehat yang tercermin dalam laporan Laba Rugi dan Neraca, sehingga dapat diperhitungkan di mata masyarakat.Kinerja keuangan bank juga dapat menggambarkan kondisi keuangan pada suatu periode yang menyangkut aspek pengimpunan dana maupun penyaluran dana, yang biasanya diukur dengan indikator kecukupan modal likuiditas, dan profitabilitas (Jumingan, 2006:54). Tujuan pengukuran kinerja keuangan perusahaan adalah mengetahui tingkat likuiditas, solvabilitas, rentabilitas, stabilitas suatu perusahaan untuk memprediksi kebangkrutan perusahaan di masa yang akan datang (Munawir, 2005:76).

Informasi keuangan bank yang tercermin dalam Laporan Laba Rugi dan Neraca ini, berguna bagi pemilik perusahaan untuk mengambil keputusan tentang kepastian investasi di masa yang akan datang untuk menghindari kerugian dalam investasi yang telah dilakukan. Jika manajemen dapat mendeteksi kebangkrutan lebih awal biasanya tindakan merger atau restrukturisasi keuangan yang akan dilakukan untuk menghindari kebangkrutan. Kebangkrutan atau kepailitan merupakan 
kegagalan perusahaan dalam menjalankan operasi perusahaan untuk menghasilkan laba. Menurut Undang-Undang Nomor 37 Tahun 2004 tentang kepailitan dan penundaan pembayaran kewajiban, menyatakan "Debitor yang mempunyai dua atau lebih kreditor dan tidak membayar sedikitnya satu utang yang telah jatuh waktu dan dapat ditagih, dinyatakan pailit dengan putusan pengadilan yang berwenang sebagaimana dimaksud dalam pasal 2, baik atas permohonan sendiri, maupun atas permintaan seorang atau lebih kreditor."

\section{Kajian Pustaka}

Menurut Undang-Undang No.10 Tahun 1998 pasal 1 ayat 2 tentang perbankan, bank adalah badan usaha yang menghimpun dana dari masyarakat dalam bentuk simpanan, dan menyalurkannya kepada masyarakat dalam bentuk kredit atau bentuk-bentuk lainnya dalam rangka meningkatkan taraf hidup rakyat banyak yang terdiri dari :

a. Bank Umum, adalah bank yang melaksanakan kegiatannya secara konvensional dan atau berdasarkan prinsip syariah dalam kegiatannya memberikan jasa dalam lalulintas pembayaran.

b. Bank Perkreditan Rakyat, adalah bank yang melaksanakan kegiatan usaha secara konvensional atau syariah dalam kegiatannya tidak memberikan jasa dalam lalu lintas pembayaran.

Kasmir (2008) bank adalah lembaga keuangan yang kegiatan utamanya menerima simpanan giro, tabungan dan deposito, kemudian bank juga dikenal sebagai tempat untuk meminjam uang (kredit) bagi masyarakat yang membutuhkannya, dimana jenis-jenis bank dapat ditinjau dari berbagai segi adalah:

1. Dilihat dari segi fungsinya

a. Bank Umum, Berdasarkan Peraturan Bank Indonesia Nomor 9/7/PBI/2007 tentang bank umum adalah bank yang melaksanakan kegiatan usaha secara konvensional dan berdasarkan prinsip syariah yang dalam kegiatannya memberikan jasa dalam lalu lintas pembayaran. Seperti memberikan kebutuhan pembiayaan serta melancarkan mekanisme system pembayaran bagi semua sector perekonomian.

b. Bank Perkreditan Rakyat, adalah bank yang melaksanakan kegiatan usaha secara konvensional atau berdasarkan prinsip syariah yang dalam kegiatannya tidak memberikan jasa dalam lalu lintas pembayaran.

c. Bank Sentral, di pegang oleh Bank Indonesia (BI). Bank Indonesia merupakan lembaga Negara yang berfungsi untuk mengawasi dan melakukan pembinaan terhadap Bank Umum dan bank Perkreditan Rakyat (BPR)

2. Dilihat dari segi kepemilikannya
a. Bank milik pemerintah
b. Bank milik swasta nasional
c. Bank milik asing
d. Bank milik campuran

3. Dilihat dari segi status
a. Bank Devisa
b. Bank Non Devisa

4. Dilihat dari segi menentukan harga

a. Bank dengan prinsip konvensional

b. Bank dengan prinsip syariah 


\section{Kegiatan Operasional Bank Umum Milik Pemerintah}

Dalam melakukan kegiatan usahanya bank umum melayani semua keinginan nasabah baik dalam menyimpan uang nasabah dan menyalurkan kembali dalam bentuk kredit. Menurut Kasmir (2008) kegiatan operasional bank umum meliputi :

a. Menghimpun dana (Funding)

b. Menyalurkan dana (lending)

c. Memberikan jasa-jasa bank lainnya (service)

Adapun Bank Umum Milik Pemerintah (BUMN) adalah:

1) PT. Bank Rakyat Indonesia Tbk (Persero), merupakan bank milik pemerintah yang didirikan oleh Raden Bei Aria Wirjaatmadja di Purwokerto Jawa Tengah dengan nama De Poerwokertosche Hulp en Spaarbank der Inlandsche Hoofden atau Bank Bantuan dan Simpanan Milik Kaum Priyayi Purwokerto. Bank BRI pada saat itu adalah suatu lembaga keuangan yang sengaja dibuat untu melayani orang-orang yang berkebangsaan Indoensia, yang sudah berdiri semenjak tanggal 16 Desember 1895 yang akhirnya dinobatkan sebagai hari milad BRI (Bank Rakyat Indonesia). Pada tanggal 1 Agustus 1992 berdasarkan Undang-Undang Perbankan No. 7 tahun 1992 dan Peraturan Pemerintah RI No. 21 tahun 1992 status BRI berubah menjadi perseroan terbatas, dimana kepemilikan BRI saat itu masih 100\% di tangan Pemerintah Republik Indonesia. Tahun 2003, Pemerintah Indonesia memutuskan untuk menjual 30\% saham bank ini, sehingga menjadi perusahaan publik dengan nama resmi PT. Bank Rakyat Indonesia (Persero) Tbk.

2) PT. Bank Negara Indonesia (Persero), didirikan pada tanggal 5 juli 1946, PT. Bank Negara Indonesia (Persero) Tbk atau BNI menjadi bank pertama milik Negara yang lahir setelah kemerdekaan Indonesia. BNI sempat berfungsi sebagai bank sentral dan bank umum sebagaimana tertuang dalam Peraturan Pemerintah Pengganti Undang-Undang No. 2/1946, sebelum akhirnya beroperasi sebagai bank komersial sejak tahun 1955. PT Bank Negara Indonesia (Persero) Tbk didirikan oleh Margono Djojohadikusumo, yang merupakan satu dari anggota BPUPKI, lalu mendirikan bank sirkulasi/sentral yang bertanggung jawab menerbitkan dan mengelola mata uang RI.

3) Bank Tabungan Negara, didirikan 09 Februari 1950 yang didirikan oleh Bapak Darmosoetanto dengan nama "Bank Tabungan Pos". Kantor Tabungan Pos dibuka pada tahun 1949 yang diganti menjadi Bank Tabungan RI. Banyak kejadian bernilai sejarah sejak 1950. Perubahan nama dari Bank Tabungan Pos menjadi BTN didasarkan pada Perpu No.4 Tahun 1964 tanggal 23 Juni 1963 yang kemudian dikuatkan dengan UU No. 2 Tahun 1964 tanggal 25 Mei 1964.

4) Bank Mandiri, didirikan pada tanggal 2 Oktober 1998 yang bagian dari program restrukturisasi perbankan yang dilaksanakan oleh pemerintah Indonesia. Bank Mandiri merupakan hasil merger antara Bank Bumi Daya (BBD), Bank Dagang Negara (BDN), Bank Pembangunan Indonesia (Bapindo) dan Bank Ekspor Impor Indonesia (Ban Exim). Hasil merger keempat bank ini dilaksanakan pada tahun 1999, dimana masing-masing bank tersebut memiliki peran yang tak terpisahkan dalam pembangunan perekonomian Indonesia. Sampai dengan hari ini, Bank Mandiri meneruskan tradisi selama lebih dari 140 tahun memberikan kontribusi dalam dunia perbankan dan perekonomian Indonesia. 
IJBE: Integrated Journal of Business and Economics

e-ISSN: 2549-3280

\section{Laporan Keuangan}

Menurut PSAK No. 1 Paragraf ke 7 (revisi 2009) menyatakan bahwa laporan keuangan adalah suatu penyajian terstruktur dari posisi keuangan dan kinerja keuangan suatu entitas. Munawir (2014) laporan keuangan adalah hasil dari proses akuntansi yang dapat digunakan sebagai alat untuk berkomunikasi antara data keuangan atau aktivitas suatu perusahaan dengan pihak-pihak yang berkepentingan dengan dana atau aktivitas perusahaan tersebut. Sawir (2005), laporan keuangan adalah hasil akhir proses akuntansi, dimana setiap transaksi yang dapat diukur dengan nilai uang, dicatat dan diolah sedemikian rupa. Laporan keuangan dibuat dengan tujuan untuk memberikan informasi atau gambaran tentang perusahaan secara periodic yang dilakukan oleh pihak manajemen yang bersangkutan.

Tujuan laporan keuangan menurut Standar Akuntansi Keuangan (SAK) yang dikutip oleh Sawir (2005), adalah:

a. Menyediakan informasi yang menyangkut posisi keuangan, kinerja serta perubahan posisi keuangan suatu perusahaan yang bermanfaat bagi sejumlah besar pemakai dalam pengambilan keputusan ekonomi.

b. Laporan keuangan disusun untuk memenuhi kebutuhan bersama oleh sebagian besar pemakainya, yang secara umum menggambarkan pengaruh keuangan dari kejadian masa lalu.

c. Laporan keuangan juga menunjukkan apa yang dilakukan manajemen atas sumber daya yang dipercayakan kepadanya.

d. Memberikan informasi tentang jenis dan jumlah kewajiban dan modal yang dimiliki perusahaan saat ini.

e. Memberikan informasi tentang kinerja manajemen perusahaan dalam suatu periode.

f. Menyediakan informasi yang dapat dipercaya tentang perubahan netto dari kekayaan sebagai hasil dari aktivitas usaha.

Menurut Gitman dan Xutter (2012) Jenis-jenis laporan keuangan adalah: "The four key financial statements required by the SEC for reporting to shareholders are (1) the income statement, (2) the balance sheet, (3) the statement of stockholders' equity, and (4) the statement of cash flows." Terdapat empat laporan keuangan utama yang dibutuhkan untuk dilaporkan kepada para pemegang saham, yaitu (1) laporan laba-rugi,(2) neraca, (3) laporan keuangan ekuitas pemegang saham, dan (4) laporan arus kas. Harahap (2009) bahwa jenis-jenis laporan keuangan adalah sebagai berikut:

1. Daftar Neraca yang menggambarkan posisi keuangan perusahaan pada suatu tanggal tertentu.

2. Perhitungan Laba/Rugi yang menggambarkan jumlah hasil, Biaya dan Laba/Rugi perusahaan pada suatu periode tertentu.

3. Laporan Sumber dan Penggunaan Dana. Di sini dimuat sumber dan penggunaan kas dalam suatu periode.

4. Laporan arus kas. Di sini digambarkan sumber dan penggunaan kas dalam suatu periode.

5. Laporan harga pokok produksi yang menggambarkan berapa dan unsur apa yang diperhitungkan dalam harga pokok produksi suatu barang.

6. Laporan Laba Ditahan, menjelaskan posisi laba ditahan yang tidak dibagikan kepada pemegang saham. 
IJBE: Integrated Journal of Business and Economics

e-ISSN: 2549-3280

7. Laporan perubahan modal, menjelaskan perubahan posisi modal baik saham PT atau Modal dalam perusahaan perseroan.

\section{Analisis Rasio Keuangan}

Menurut Fahmi (2014) rasio keuangan terdiri dari :

1. Rasio Likuiditas, rasio ini menggambarkan kemampuan perusahaan dalam melunasi kewajiban jangka pendeknya secara tepat waktu

2. Rasio solvabilitas menggambarkan tentang kemampuan perusahaan dalam melunasi kewajiban jangka panjangnya atau kewajiban-kewajiban saat perusahaan dilikuidasi

3. Rentabilitas/Profitabilitas, rasio inimenggambarkan kemampuan perusahaan dalam memanfaatkan sumber daya (SDM, modal, kas) yang ada untuk menghasilkan laba untuk perusahaan.

4. Rasio Leverage menggambarkan tentang utang perusahaan terhadap asset atau modal. Rasio ini digunakan untuk melihat sejauh mana kemampuan perusahaan dibiayai oleh utang jika dibandingkan dengan kemampuan perusahaan jika dilihat dengan modal sendiri atau ekuitas.

5. Rasio aktivitas menggambarkan kemampuan perusahaan dalam menjalankan operasinya seperti kegiatan penjualan, pembelian, dan kegiatan lainnya.

6. Rasio Pertumbuhan menggambarkan seberapa besar kemampuan perusahaan dalam mempertahankan posisinya di dalam industri dan dalam perkembangan ekonomi secara.

7. Penilaian pasar menggambarkan situasi/keadaan prestasi perusahaan di pasar modal.

8. Rasio produktivitas menunjukkan tingkat produktivitas dari unit atau kegiatan yang dinilai dengan menilai dari segi produktivitas unit-unitnya

\section{Financial Distress}

Financial distress atau kebangkrutan atau bangkrut sering juga disebut dengan kesulitan keuangan atau ketidakmampuan perusahaan untuk membayar kewajiban jangka pendek maupun jangka panjang yang sudah jatuh tempo. Pengelolaan kesulitan keuangan jangka pendek (tidak mampu membayar kewajiban pada saat jatuh tempo) yang tidak tepat akan menimbulkan permasalahan yang lebih besar yaitu menjadi tidak solvable (jumlah utang lebih besar daripada jumlah aset) dan akhirnya mengalami kebangkrutan (Munawir, 2014). Darsono dan Ashari (2005) mendeskripsikan bahwa secara garis besar penyebab kebangkrutan berasal dari faktor internal seperti bagian internal manajemen perusahaan dan faktor eksternal berupa yang berhubungan langsung dengan operasi perusahaan atau faktor perekonomian secara makro. Berikut beberapa definisi financial distress yang berkaitan informasi dalam laporan keuangan menurut beberapa ahli Sri Mulyati (2017):

1. Kristijadi (2003) menyatakan financial distress adalah kondisi dimana perusahaan mengalami laba bersih operasi (net operation income) negatif selama beberapa tahun dan selama lebih dari satu tahun tidak melakukan pembayaran deviden, pemberhentian tenaga kerja atau menghilangkan pembayaran dividen.

2. Luciana (2006) menyatakan financial distress adalah kondisi dimana perusahaan mengalami delisted akibat laba bersih dan nilai buku ekuitas negatif berturut-turut serta perusahaan tersebut telah di-merger.

3. Atmini (2005) mendefinisikan financial distress jika melakukan pemberhentian tenaga kerja atau menghilangkan pembayaran dividen. 
4. Endri (2009), mengategorikan kondisi financial distress berdasarkan kriteria dari informasi Wall Street Journal Index (WSJI). debt default, yaitu terjadinya kegagalan membayar hutang atau terdapat indikasi kegagalan membayar hutang (debt default) dengan melakukan negosiasi ulang dengan kreditur atau institusi keuangan lainnya.

Fachrudin (2008) kebangkrutan sebagai kegagalan didefinisikan dalam beberapa arti yaitu:

a. Kegagalan Ekonomi (Economic Failure)

b. Kegagalan Usaha (Business Failure)

c. Insolvensi Teknis (Technical Insolvency)

Menurut Permana (2007:97) membagi penyebab kebangkrutan yaitu:

1. Sektor ekonomi, dimana berawal dari gejala inflasi dan deflasi dalam harga barang dan jasa, kebijakan keuangan, suku bunga, dan devaluasi atau revaluasi mata uang asing.

2. Sektor sosial, dimana yang sangat berpengaruh adalah adanya perubahan gaya hidup masyarakat yang mempengaruhi permintaan terhadap produk dan jasa ataupun yang berhubungan dengan karyawan

3. Sektor teknologi, dimana penggunaan teknologi memerlukan biaya yang ditanggung perusahaan terutama untuk pemeliharaan dan implementasi.

4. Sektor pemerintah, dimana kebijakan pemerintah terhadap pencabutan subsidi pada perusahaan dan industri, pengenaan tarif, ekspor dan impor bisa berubah, kebijakan Undang-Undang baru bagi perbankan atau tenaga kerja dan lain-lain.

5. Sektor pelanggan/nasabah, dimana untuk menghindari kehilangan nasabah bank harus melakukan identifikasi terhadap sifat nasabah atau konsumen juga menciptakan peluang untuk mendapatkan nasabah baru.

6. Sektor kreditur, dimana kekuatan terletak pada pemberian pinjaman dan penetapan jangka waktu pengembalian hutang piutang yang tergantung pada kepercayaan kreditor terhadap likuiditas suatu bank.

7. Sektor pesaing/bank lain, dimana merupakan hal yang harus diperhatikan karena menyangkut perbedaan pemberian pinjaman kepada nasabah.

8. Terlalu besarnya kredit yang diberikan kepada nasabah sehingga menyebabkan adanya penunggakan dalam pembayaran sampai akhirnya tidak dapat membayar.

9. Manajemen yang tidak efisien yang disebabkan karena kurang adanya kemampuan, pengalaman, keterampilan, sikap adaptif dan inisiatif dari manajemen.

10. Penyalahgunaan wewenang dan kecurangan-kecurangan, dimana sering dilakukan oleh karyawan, bahkan manajer puncak sekalipun yang sangat merugikan apalagi yang berhubungan dengan keuangan perusahaan.

\section{Metode Penelitian}

Jenis penelitian ini adalah penelitian deskriptif kuantitatif yaitu. Menurut Sugiyono (2012:13) penelitian deskriptif kuantitatif adalah metode penelitian yang berlandaskan pada filsafat positivisme yaitu menekankan pada pengujian teori-teori melalui pengukuran variabel-variabel penelitian dengan angka-angka dan melakukan analisa angka dengan pada populasi atau sampel tertentu. Dengan pengumpulan data menggunakan penelitian serta analisis data bersifat kuantitatif. Menurut Harun (2007:34) analisis data adalah proses menyusun data agar dapat ditafsirkan. Metode analisis data digunakan dalam penelitian ini untuk memprediksi 
kebangkrutan dengan menggunakan model prediksi Altman Z-Score (Mamduh dan Halim, 2009: 274) dengan rumus:

$$
Z=1,2 X 1+1,4 X 2+3,3 X 3+0,6 X 4+1.0 X 5
$$

Dimana :

$\mathrm{Z}=$ Bunkrupcy Index

$\mathrm{X} 1=$ Working Capital/Total Assets

$\mathrm{X} 2$ = Retained Earnings/Total Assets

X3 = Net Profit Margin Before Interest and Taxes/Total Assets

X4 = Market Value of Equity /Book Value of Debt

$\mathrm{X} 5=$ Sales/Total Asset

Keterangan :

$\mathrm{X} 1$ = Working Capital/Total Assets (Modal Kerja/Total Aset), Rasio ini digunakan untuk mengukur dan membandingkan modal kerja perusahaan dengan total aset yang dimiliki oleh perusahaan. Bila perusahaan mengalami kesulitan keuangan, modal kerja akan turun lebih cepat daripada total aktiva. Jika rasio ini negative, maka perusahaan mengalami masalah dalam memenuhi kewajiban jangka pendeknya, namun jika rasio ini positif maka perusahaan tidak menghadapi kesulitan dalam membayar kewajibannya.

$$
\text { Rasio Modal kerja dengan aktiva : } \frac{\text { Modal Sendiri }}{\text { Total Aset }}
$$

X2 = Retained Earning/Total Asset atau laba ditahan/total aset, Rasio laba ditahan terhadap modal aktiva ini menggambarkan jumlah keseluruhan dari pendapatan perusahaan yang diinvestasikan ke dalam perusahaan yaitu aset perusahaan yang dibiayai dengan menggunakan laba ditahan, bila perusahaan rugi maka laba ditahan akan menjadi negatif.

$$
\text { Rasio laba ditahan dengan aset : } \frac{\text { Laba ditahan }}{\text { Total Aset }}
$$

X3 = Net Profit Margin Before Tax/total asset (laba bersih sebelum pajak/total aset), Rasio ini untuk mengukur kemampuan tingkat pengembalian/produktifitas aktiva perusahaan sebelum pembayaran pajak dengan total aktiva. Rasio ini merupakan rasio keuangan yang mengukur tingkat produktifitas perusahaan dalam menghasilkan laba.

$$
\text { Return On Investment }(\mathrm{ROI})=\frac{\text { Laba Bersih sebelum pajak }}{\text { Total Aset }}
$$

X4 = Book Value of Equity/book value of debt atau Nilai pasar modal/nilai buku utang, Rasio ini menunjukkan kemampuan perusahaan untuk memenuhi kewajiban-kewajiban pasar modal sendiri (saham biasa). Nilai pasar ekuitas sendiri diperoleh dengan mengalikan jumlah lembar saham biasa yang beredar dengan harga pasar perlembar saham biasa. Nilai buku utang diperoleh dengan menjumlahkan kewajiban lancar dan kewajiban jangka panjang.

$$
\text { modal/nilai utang atau total hutang) : } \frac{\text { Nilai Pasar Modal }}{\text { Total utang }}
$$


X5 = Sales/Total Asset (penjualan atau pendapatan/ total aset), Rasio ini yaitu rasio penjualan terhadap total aktiva yang menggambarkan kemampuan perusahaan dalam meningkatkan penjualan dari aktiva perusahaan yang merupakan suatu ukuran dari kemampuan manajemen dalam menghadapi kondisi yang kompetitif. Jika rasio ini rendah mengindikasikan bahwa pihak manajemen perusahaan kurang efektif dalam mengelola aset yang dimiliki perusahaan untuk menghasilkan penjualan yang lebih tinggi.

$$
\text { Rasio perputaran aset usaha }=\frac{\text { Penjualan }}{\text { Total Aset }}
$$

\section{Kriteria nilai Z-Score:}

Dengan menggunakan nilai cut off 2,675 dan 1,81 Altman membagi perusahaan berdasarkan nilai Z-score masing-masing perusahaan menjadi 3 kategori yaitu :

a. Jika $Z>2,99$ maka perusahaan dikategorikan sebagai perusahaan yang sehat atau tidak potensial bangkrut

b. Jika $1,81<\mathrm{Z}<2,99$ maka perusahaan dalam grey area, yaitu perusahaan mengalami masalah dalam keuangannya

c. Jika nilai $\mathrm{Z}<1,81$ maka perusahaan tidak sehat atau potensial bangkrut.

Adapun langkah- langkah yang dilakukan dalam proses analisis ini adalah sebagai berikut:

1. Menghitung rasio keuangan bank tiap tahunnya meliputi X1,X2,X3,X4, dan X5.

2. Menghitung nilai $\mathrm{Z}-\mathrm{Score}(\mathrm{Z}=1,2 \mathrm{X} 1+1,4 \mathrm{X} 2+3,3 \mathrm{X} 3+0,6 \mathrm{X} 4+1,0 \mathrm{X} 5)$

3. Menghitung masing-masing skor dengan menggunakan formula Altman Z-Score.

4. Mengategorikan masing-masing perusahaan sesuai dengan cut off yang sudah ditentukan.

5. Menarik kesimpulan kinerja keuangan bank memprediksi kebangkrutan.

\section{Pembahasan Hasil}

Bank Umum Milik Pemerintah yaitu lembaga keuangan yang kegiatannya menghimpun dana dari masyarakat dalam bentuk tabungan dan menyalurkannya kepada masyarakat dalam bentuk kredit. Bank Umum Milik Pemerintah (BUMN) merupakan bank yang seluruhnya atau sebagian besar modalnya dimiliki oleh pemerintah, dimana kegiatan utamanya adala :

1. Menghimpun dana dari masyarakat dalam bentuk giro, deposito berjangka, sertifikat deposito, tabungan, dan atau bentuk lainnya yang dapat dipersamakan dengan itu.

2. Menyalurkan dana kepada masyarakat dalam bentuk kredit.

3. Menerbitkan surat pengakuan utang.

4. Membeli, menjual, atau menjamin atas risiko sendiri maupun untuk kepentingan nasabah dan atas perintah nasabahny seperti surat wesel, obligasi, surat jaminan pemerintah dan sertifikasi Bank Indonesia.

\section{Model Altman Z-score Dalam Memprediksi Kebangkrutan Bank Umum Milik Pemerintah} Jumlah perusahaan perbankan yang menjadi sampel dalam penelitian ini adalah Bank Umum Milik Pemerintah (BUMN) yaitu Bank Rakyat Indonesia, Bank Negara Indonesia, Bank Tabungan Negara dan Bank Mandiri, dengan Periode pengamatan selama 3 tahun yaitu dari tahun 2014 sampai dengan tahun 2016. Berdasarkan data dari laporan keuangan Bank Rakyat Indonesia, Bank Negara Indonesia, Bank Tabungan Negara dan Bank Mandiri (Lampiran 1), 
Berikut hasil perhitungan rasio keuangan Bank Rakyat Indonesia, Bank Negara Indonesia, Bank Tabungan Negara dan Bank Mandiri tahun 2014, 2015 dan 2016 yang dinyatakan dalam X1, X2, X3, X4 dan X5 yang digunakan untuk memprediksi kebangkrutan di masa yang akan datang

Tabel 1. Hasil Perhitungan Rasio Keuangan

\begin{tabular}{|c|c|c|c|c|c|c|c|}
\hline No. & Bank & Tahun & X1 & $\mathbf{X} 2$ & $\mathrm{X3}$ & X4 & X5 \\
\hline \multirow[t]{3}{*}{1} & \multirow{3}{*}{$\begin{array}{l}\text { Bank Rakyat Indonesia } \\
\text { (Persero)Tbk }\end{array}$} & 2014 & 0,12 & 0,11 & 0,04 & 0,40 & 0,04 \\
\hline & & 2015 & 0,13 & 0,12 & 0,04 & 0,37 & 0,03 \\
\hline & & 2016 & 0,15 & 0,12 & 0,03 & 0,33 & 0,03 \\
\hline \multirow[t]{3}{*}{2} & \multirow{3}{*}{$\begin{array}{l}\text { Bank Negara Indonesia } \\
\text { (Persero)Tbk }\end{array}$} & 2014 & 0,15 & 0,08 & 0,03 & 0,33 & 0,03 \\
\hline & & 2015 & 0,15 & 0,08 & 0,02 & 0,23 & 0,02 \\
\hline & & 2016 & 0,15 & 0,08 & 0,02 & 0,21 & 0,02 \\
\hline \multirow[t]{3}{*}{3} & \multirow{3}{*}{$\begin{array}{l}\text { Bank Tabungan Negara } \\
\text { (Persero) Tbk }\end{array}$} & 2014 & 0,08 & 0,04 & 0,01 & 0,21 & 0,01 \\
\hline & & 2015 & 0,08 & 0,29 & 0,01 & 0,19 & 0,01 \\
\hline & & 2016 & 0,09 & 0,04 & 0,02 & 0,21 & 0,02 \\
\hline \multirow[t]{3}{*}{4} & \multirow[t]{3}{*}{ Bank Mandiri (Persero) Tbk } & 2014 & 0,12 & 0,09 & 0,03 & 0,15 & 0,03 \\
\hline & & 2015 & 0,13 & 0,10 & 0,03 & 0,13 & 0,03 \\
\hline & & 2016 & 0,15 & 0,09 & 0,02 & 0,01 & 0,02 \\
\hline
\end{tabular}

Sumber : Data diolah peneliti, 2017

Dalam memprediksi kebangkrutan model Altman menggunakan persamaan yaitu $\mathrm{Z}=1,2 \mathrm{X} 1+$ $1,4 \mathrm{X} 2+3,3 \mathrm{X} 3+0,6 \mathrm{X} 4+1,0 \mathrm{X} 5$, dengan menggunakan nilai cut off sebesar 2,675 dan 1,81 artinya jika skor yang diperoleh Bank Umum Milik Pemerintah $Z>2,675$, maka perusahaan dikategorikan sebagai perusahaan yang sehat dan tidak mengalami financial distress (tidak potensial bangkrut), jika skor $1,81<\mathrm{Z}<2,675$, maka perusahaan dalam Grey Area artinya perusahaan mengalami masalah dalam keuangannya (tidak dapat diprediksi), jika skor $\mathrm{Z}<1,81$ artinya termasuk perusahaan yang tidak sehat dan mengalami masalah financial distress (potensial bangkrut). Berikut hasil perhitungan dan persamaan model Altman untuk memprediksi kebangkrutan pada Bank Umum Milik Pemerintah tahun 2014, 2015 dan 2016 adalah :

Tabel 2. Hasil Perhitungan Model Altman Z-Score

\begin{tabular}{|c|c|c|c|l|}
\hline No. & Bank & Tahun & Z-Score & \multicolumn{1}{|c|}{ Keterangan } \\
\hline 1 & Bank Rakyat Indonesia (Persero)Tbk & 2014 & 4,200 & $\begin{array}{l}\text { Tidak Potensial } \\
\text { Bangkrut }\end{array}$ \\
\cline { 3 - 5 } & & 2015 & 4,144 & $\begin{array}{l}\text { Tidak Potensial } \\
\text { Bangkrut }\end{array}$ \\
\cline { 3 - 5 } & & 2016 & 4,047 & $\begin{array}{l}\text { Tidak Potensial } \\
\text { Bangkrut }\end{array}$ \\
\hline 2 & Bank Negara Indonesia (Persero)Tbk & 2014 & 3,803 & $\begin{array}{l}\text { Tidak Potensial } \\
\text { Bangkrut }\end{array}$ \\
\cline { 3 - 5 } & & 2015 & 2,753 & Grey area \\
\cline { 3 - 5 } & & 2016 & 2,858 & Grey area \\
\hline 3 & Bank Tabungan Negara (Persero) Tbk & 2014 & 1,405 & Potensial Bangkrut \\
\cline { 3 - 5 } & & & & \\
\end{tabular}


IJBE: Integrated Journal of Business and Economics

e-ISSN: 2549-3280

\begin{tabular}{|c|c|c|c|l|} 
& & 2015 & 2,138 & Grey area \\
\hline 4 & Bank Mandiri (Persero) Tbk & 2016 & 1,906 & Grey area \\
\hline 4 & 2014 & 3,497 & $\begin{array}{l}\text { Tidak Potensial } \\
\text { Bangkrut }\end{array}$ \\
\cline { 3 - 5 } & & 2015 & 3,364 & $\begin{array}{l}\text { Tidak Potensial } \\
\text { Bangkrut }\end{array}$ \\
\cline { 3 - 5 } & & 2016 & 2,168 & Grey area \\
\hline
\end{tabular}

Sumber : Data diolah peneliti, 2017

Hasil perhitungan nilai Z-score pada tabel 2 di atas dengan menggunakan persamaan model Altman dalam memprediksi kebangkrutan pada Bank Umum Milik Pemerintah yaitu PT. Bank Rakyat Indonesia (Persero) Tbk dikategorikan sebagai perusahaan yang sehat atau tidak potensial bangkrut, dimana nilai Z-score tahun 2014 sebesar 4,200, tahun 2015 sebesar 4,144 dan tahun 2016 sebesar 4,047 ini menunjukkan bahwa nilai Z-score berada di atas 2, 99 artinya PT. Bank Rakyat Indonesia (Persero) Tbk termasuk dalam perusahaan yang sehat.

PT. Bank Negara Indonesia (Persero) Tbk, pada tahun 2014 termasuk perusahaan yang sehat atau tidak potensial bangkrut ini ditunjukkan dengan nilai Z-score sebesar 3,803, sedangkan tahun 2015 dan 2016 PT. Bank Negara Indonesia (Persero) Tbk berada pada kondisi grey area (tidak dapat diprediksi) dengan hasil nilai Z-score tahun 2015 sebesar 2,753 dan tahun 2016sebesar 2,858 ini menunjukkan bahwa PT. Bank Negara Indonesia (Persero) Tbk termasuk perusahaan yang tidak potensial bangkrut dan juga dapat potensial bangkrut.

PT. Bank Tabungan Negara (Persero) Tbk tahun 2014 dengan nilai Z-score 1,405 artinya termasuk perusahaan yang tidak sehat atau potensial bangkrut, sedangkan tahun 2015 dan 2016 PT. Bank Tabungan Negara (Persero) Tbk berada pada kondisi grey area (tidak dapat diprediksi) dengan hasil nilai Z-score tahun 2015 sebesar 2,138 dan tahun 2016 sebesar 1,906 ini menunjukkan bahwa PT. Bank Tabungan Negara (Persero) Tbk termasuk perusahaan yang tidak potensial bangkrut dan juga dapat potensial bangkrut.

PT. Bank Mandiri (Persero) Tbk, tahun 2014 dan tahun 2015 masuk dalam kategori perusahaan sehat atau tidak potensial bangkrut dengan nilai Z-score tahun 2014 sebesar 3,497 dan tahun 2015 sebesar 3,364, sedangkan pada tahun 2016 berada pada posisi grey area (tidak dapat diprediksi) ini menunjukkan bahwa PT. Bank Mandiri (Persero) Tbk termasuk perusahaan yang dapat potensial bangkrut dan juga tidak potensial bangkrut.

Prediksi kebangkrutan terhadap perusahaan Bank Umum Milik Pemerintah yang mengakibatkan perusahaan potensial bangkrut karena perusahaan mengalami penurunan laba bersih dan tidak mampu membayar utang jangka panjang perusahaan sesuai dengan teori yang dikemukakan oleh Elloumi dan Gueyie dalam Parulian (2007), potensial bangkrut dapat disebab juga oleh ketidakmampuan perusahaan untuk membayar kewajiban keuangannya pada saat jatuh tempo dan manajemen tidak bisa menggunakan modal kerja secara efektif. Nilai rasio solvabilitas dan rasio profitabilitas perusahaan yang rendah dapat mengakibatkan perusahaan potensial bangkrut disebabkan oleh menurunnya kondisi keuangan yang dialami perusahaan yang terjadi sebelum kebangkrutan atau likuidasi. Menurut Munawir (2014:56) pengelolaan kesulitan keuangan jangka panjang (tidak mampu membayar kewajiban pada saat jatuh tempo) yang tidak tepat akan menimbulkan permasalahan yang lebih besar yaitu menjadi tidak solvable 
(jumlah hutang lebih besar daripada jumlah aset) dan akhirnya mengalami kebangkrutan. Kemampuan Bank Umum Milik Pemerintah dalam membayar kewajiban jangka pendek dan kewajiban jangka panjang dengan menggunakan aktiva yang dimiliki oleh perusahaan dapat meningkatkan kinerja perusahaan di masa yang akan datang dan perusahaan dapat terhindar dari kondisi potensial bangkrut.

\section{Kesimpulan}

1. Perusahaan yang termasuk dalam perusahaan sehat atau tidak potensial bangkrut adalah PT. Bank Rakyat Indonesia (Persero) Tbk tahun 2014 dengan nilai Z-score 4,200, tahun 2015 nilai Z-score sebesar 4,144 dan tahun 2015 dengan nilai Z-score 4,047. PT. Bank Negara Indonesia (Persero) Tbk Tahun 2014 dengan nilai Z-score sebesar 3,803 dan PT. Bank Mandiri (Persero) Tbk tahun 2014 dan 2015 dengan nilai Z-score sebesar 3,497 dan 3, 365.

2. Perusahaan yang termasuk dalam kategori perusahaan tidak sehat atau potensial bangkrut adalah PT. Bank Tabungan Negara (Persero) Tbk pada tahun 2014 dengan nilai Z-score kurang dari 1,81 yaitu sebesar 1,405.

3. Perusahaan yang termasuk dalam Grey Area (tidak dapat diprediksi) adalah PT. Bank Negara Indonesia (Persero) Tbk tahun 2015 dengan nilai Z-score 2, 753 dan tahun 2016 dengan nilai Z-score 2,858. PT Bank Tabungan Negara pada tahun 2015 dan 2016 dengan nilai Z-score 2,138 dan 1,906. dan PT. Bank Mandiri (Persero) Tbk tahun 2016 yang menunjukkan nilai Z-score sebesar 2, 168.

\section{Referensi}

Beaver, William H. (1966). Financial Ratios as Predictors of Failure. Journal of Accounting Research, Supplement

Darsono dan Ashari. (2005). Pedoman Praktis Memahami Laporan Keuangan. Andi Publisher

Elloumi, F. and Gueyie, J.P. (2001). Financial Distress and Corporate. Governance: An Empirical Analysis. Corporate Governance. Universitas Sumatera Utara

Fachrudin. Amalia, K. (2008). Kesulitan Keuangan Perusahaan dan Pesonal. Medan: USU Press

Fahmi, I. (2014). Analisis Laporan Keuangan. Bandung: Alfabeta

Gitman dan Xutter. (2012). Principle of Managerial Finance. 13th Edition. Global Edition: Pearson Eduaction Limited

Halim. et al. (2009). Analisa Laporan Keuangan. Yogyakarta: UPP AMP YKPN

Harahap, S. S. (2011). Analisis Kritis Atas Laporan Keuangan. Jakarta : Raja Grafindo Persada

Harun. (2007). Statistika Sosial. Bandung:Program Pascasarjana UNPAD 
Jumingan. (2006). Analisis Laporan Keuangan, Cetakan Pertama, Jakarta: PT Bumi Aksara

Kasmir. (2008). Manajemen Perbankan. Edisi Revisi. Jakarta: PT. Raja Grafindo Persada.

Martono dan Harjito, A. (2010). Manajemen Keuangan. Yogyakarta: Ekonesia

Munawir, S. (2005). Analisa Laporan Keuangan. Yogyakarta: Liberty

Munawir, S. (2014). Analisa Laporan Keuangan. Yogyakarta: Liberty

Peraturan Bank Indonesia Nomor 9/7/PBI/2007 Tentang Bank Umum

Permana, Y. (2009). Implementasi Metode X-Score dan Y-Score Untuk Memprediksi

Kebangkrutan Perusahaan : Studi Kasus Pada Perusahaan Manufaktur DI BEI Periode 2003-2005. Fakultas Ekonomi, Universitas Negeri Malang

Sartono, A. (2012). Manajemen Keuangan Teori dan Aplikasi. Yogyakarta: BPFE.

Sugiyono. (2012). Metode Penelitian Bisnis. Bandung: CV. Alfabeta.

Undang-undang No.10 Tahun 1998 tentang perbankan

UU RI No.4 Tahun 1998 yang diperbaharui dengan Undang-Undang Nomor 37 Tahun 2004 tentang kepailitan dan penundaan pembayaran kewajiban

Zu'amah, S. (2005). Perbandingan Ketepatan Klasifikasi Model Prediksi Kepailitan Berbasis Akrual dan berbasis Aliran Kas. SNA VIII, hal 441-459. 